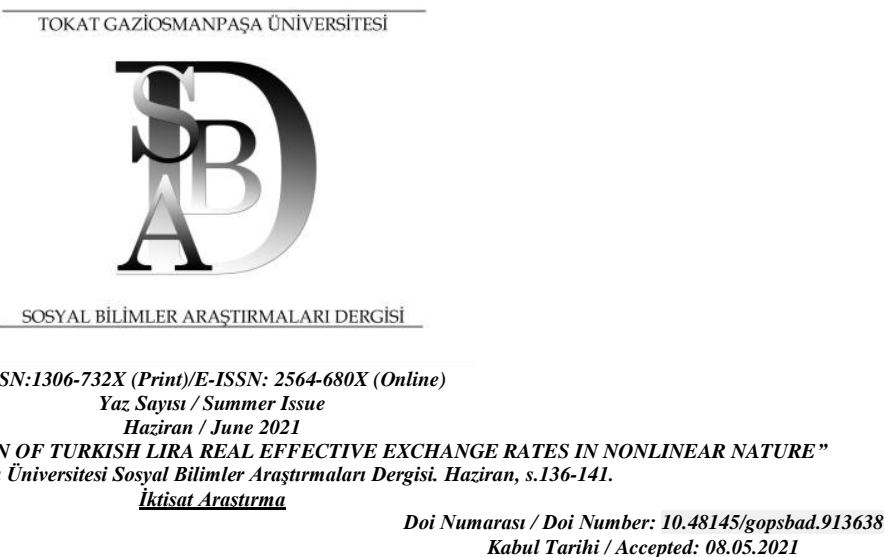

\title{
EMPIRICAL INVESTIGATION OF TURKISH LIRA REAL EFFECTIVE EXCHANGE RATES IN NONLINEAR NATURE
}

\author{
Mustafa NAL ${ }^{1 *+}$ \\ ${ }^{1}$ Araştırma Görevlisi Dr. Hitit Üniversitesi, İktisadi ve İdari Bilimler Fakültesi, İktisat Bölümü \\ "mustafanal@hitit.edu.tr \\ +ORCID: 0000-0001-6190-6437
}

\begin{abstract}
In this paper, the tendency properties of Turkish real effective exchange rate with an inaction band are examined in nonlinear nature. The general SETAR (3) model is used. This is a convenient way of presenting the inactivity band caused by the transfer costs and other factors. In this modelling, the stationarity is defined globally which is allow to unit root in the corridor regime but the outers regimes must be a mean reverting process. The data are used de-meaned and de-trended form. For de-meaned data, we execute both the linearity and the stationarity tests. For de-trended data, only the linearity test is executed. According to our empirical results, the statistical evidence is poor for the validity of PPP in even nonlinear nature. The null of unit root is not rejected for the CPI based reel effective exchange rate and it is rejected only 5\% significance level for PPI based one. However, take into account possibility of the existence of trend component, Turkish real effective exchange rates are well characterized by nonlinear process with inactivity band and a tendency property. While these findings support the transaction costs hypothesis, they do not strongly support the validity of the PPP hypothesis.
\end{abstract}

Keywords-Nonlinear adjustment, Purchasing power parity, Transaction cost, SETAR

\section{TÜRK LİRASI REEL EFEKTIF DÖVIZ KURLARININ DOĞRUSAL OLMAYAN YAPIDA AMPIRIK İNCELEMESI}

$\ddot{O} z$-Bu çalışmada, Türk lirası reel efektif döviz kurlarının doğrusal olmayan nitelikteki eğilim özellikleri genel SETAR (3) model kullanılarak incelenmiştir. SETAR (3) model, transfer maliyetleri ve diğer faktörlerin neden olduğu hareketsizlik bandını göstermenin uygun bir yoludur. Bu modellemede, durağanlık global olarak tanımlanmaktadır. Global durağan süreçte koridor rejim birim kök sürecine sahip olabilirken, diş rejimler ortalamaya yönelen bir sürece sahip olması gerekmektedir. Analiz, ortalamadan ve eğilimden arındırılmış veriler için ayrı ayrı gerçekleştirilmiştir. Ortalamadan arındırılmış veriler için, hem doğrusallık hem de durağanlık testleri uygulanmıştır. Eğilimden arındırılmış veriler için ise yalnızca doğrusallık testi gerçekleștirilmiştir. Analiz sonuçlarına göre, CPI bazlı reel efektif döviz kuru için birim kök boş hipotezi reddedilememişken ve ÜFE bazlı olan için sadece\% 5 anlamlılık seviyesinde ret edilebilmiştir. Buna göre doğrusal olmayan yapıda bile PPP'nin geçerliliği için istatistiksel kanıtlar zayıftır. Bununla birlikte trend bileşeninin var olma olasılığını hesaba katıldığında, Türk lirası reel efektif döviz kurları bir hareketsizlik bandının çevresinde yakınsama özelliğine sahip olduğuna yönelik güçlü istatistikler kanıtlar bulunmaktadır. Bu sonuçlar işlem maliyeti hipotezini desteklemekte iken satın alma gücü paritesi hipotezini güçlü bir şekilde desteklememektedir.

Anahtar Kelimeler-Doğrusal olmayan ayarlama, Satın alma gücü paritesi, Isşlem maliyetleri, SETAR. 


\section{INTRODUCTION}

The nonlinear adjustment of real exchange rate means that the speed of mean reversion depends on absolute size of deviation from the equilibrium level. Several arguments have been proposed for this type behavior. The transaction cost is the most famous and frequently used. It has a long history in economic thought. Heckscher (1916) first mentioned the importance of this costs. His suggestion is that in the framework of spatially separated markets the shipping cost and trade barrier create a price differential for similar commodities (such as gold). The suggestion has turned into a bundle of thought explaining the nonlinear movement of the real exchange rate, with many contributions (Bec et al., 2004; Beninga and Protopapadakis, 1988; Dumas, 1992; William and Wright, 1991). In addition, some economists have also suggested several factors that may induce nonlinear adjustment such as target zone (Krugman,1991), heterogeneous opinions on the equilibrium exchange rate (Kilian and Taylor, 2003), official intervention (Taylor, 2004). Although there is substantial difference in details of the models, most of these imply a band (or inaction band) in which the behavior of reel exchange rate is not a mean reverting process. Out of the band there is a tendency to within.

The presence of nonlinearity is especially important for the statistical power of unit root tests. Granger and Teräsvirta (1993) showed that the power of standard unit root tests weakens when true data generating process is nonlinear. Therefore, the nonlinear adjustment has attracted particular attention from the proponents of purchasing power parity (PPP). In fact, after the first wave studies which could not reject non stationarity, the unit root was rejected for the among developed countries reel exchange rates in the second wave studies using longspan data and panel data. However, the high of persistence deviation from the equilibrium (or PPP) is remained an open question. Taylor, Peel and Sarno (2001) argued that the nonlinear adjustment is possible explanation of the slow speed of mean reversion and the near random walk process. The behavior of real exchange rate makes as if random walk close and within the band which contain the PPP equilibrium level. In addition, the small deviation from PPP will be high persistence because of the mean reverting process is not work or very slow.

Recently, research on Turkish real exchange rate has focused on structural breaks and regime change. Y1ldırım and Yıldırım (2012), Şener et al. (2015), Kalyoncu et al (2010), Kula et al. (2011) and Kum (2012) show that the PPP hypothesis is valid with structural break in Turkey. Sarno (2000), Alba and Park (2005) provide evidence that the real bilateral Turkish lira exchange rates aganist its major trading partners behave nonlinearly. In addition, Yıldırım (2017) reach if nonlinear unit root test is employed Turkish lira reel exchange rate is stationary. These studies mostly focused on testing the validity of PPP in a non-linear structure.
This study examines the tendency properties of Turkish real effective exchange rate with an inaction band in nonlinear nature. General three regime self-exciting threshold autoregressive model is used. This modelling is similiar to Alba and Park (2005) in respect to discrete adjustment but they use two regime threshold model. Since main objective in this study is investigation to existence of inaction band, the analysis is executed with both de-meaned and de-trended data. For the de-meaned data, we also test the stationarity as globally. Indeed, this is equivalent to testing validity of PPP in the nonlinear nature. Using de-trended data which is applied by Obstfeld and Taylor (1997) to disaggregated data, we admit the possibility to existence of a trend component in the real exchange rates. There is a literature which is concerned with it (for example, Blassa, 1964; Canzoneri et al.,1996; Chinn and Johnston,1996; Obstfeld, 1993). Obstfeld and Rogoff (1994) and Hooper and Morton (1982) provided statistical evidence on relation between cumulated current account deficit and long run real exchange rate depreciation. For a long time, Turkey has suffered from current account deficit and growing foreign debt. It could be the reason for the existence of the trend component. Since our main concern is short run nonlinear dynamics, we will leave the detailed analysis on the determinants of the trend component for further studies.

The rest of the article is structured as follow. In the next section we briefly describe our estimating and testing procedure. In section 3 we report the estimation. The final section records the conclusions.

\section{METHODOLOGY}

The characterization of nonlinear dynamics we consider is three regime SETAR model (sometimes called the TAR) where the speed of adjustment varies among the regimes but within a regime it is not change. That is the slope coefficients are allowed to discrete switch between the regimes.

The model we choose is quite general defined SETAR (3) model;

$$
\begin{aligned}
& \mathrm{y}_{t} \\
& = \begin{cases}\mu_{1}+\alpha_{11} y_{t-1}+\ldots+\alpha_{1 p} y_{t-p}+\varepsilon_{t} & \text { if } y_{t-d} \leq \lambda_{1} \\
\mu_{2}+\alpha_{21} y_{t-1}+\ldots+\alpha_{2 p} y_{t-p}+\varepsilon_{t} & \text { if } \lambda_{1}<y_{t-d}<\lambda_{2} \\
\mu_{3}+\alpha_{31} y_{t-1}+\ldots+\alpha_{3 p} y_{t-p}+\varepsilon_{t} & \text { if } y_{t-d} \geq \lambda_{2}\end{cases}
\end{aligned}
$$

where $p$ is lag order, $d$ is delay parameter and $\lambda_{1}, \lambda_{2}$ are threshold values such that $-\infty<\lambda_{1}<\lambda_{2}<\infty$. The delay parameter shows the delay in which the signal is received to change the regime.

We consider three problems for this specification. First how can this model be estimated? Second whether or not the nonlinear model is superior for our data? Third, are Turkish real effective exchange rates stationary in nonlinear nature? In this section we will briefly explain the procedures to be used for these problems. In fact, the 
second and third problems are hypotheses that need to be tested. Kapetanios and Shin (2006) developed sup Wald test procedure to test linearity and stationarity jointly. However, Bec at al. (2004) argued that in such a test process, if a series has strong nonlinearity, the test statistics can be high and the null hypothesis can be rejected even the series is non stationary. We will follow the second approach. Stationarity and linearity will be tested separately.

In nonlinear models (like model 1), the standard estimation procedures are not implemented. As threshold value is known, the estimation can be done performing LS by a dummy variable. But it is generally unknown in practice. Chan (1993) developed a procedure (called grid search) to obtain a super consistent estimate of the threshold. The logic of the procedure is as follows. If true model is nonlinear for $y_{t}$ then the threshold value lies between $\min \left\{y_{t}\right\}$ and $\max \left\{y_{t}\right\}$. When $y_{t}$ is estimated with using each observation in interval $\left[\min \left\{y_{t}\right\}, \max \left\{y_{t}\right\}\right]$ as a threshold value, the smallest sum squared residuals (SSR) is obtained from the estimation that used true one.

In the implementation of grid search, $y_{\text {order }}$ is obtained by ordering to the observations from the smallest to the highest. The both side $\omega \%$ extremes of $y_{\text {order }}$ are excluded so that each regime has sufficient number of observations. $\omega$ is determined by the length of sample. It may be higher for small samples. Using each unit of the remaining series as a threshold value, the estimation is repeated to find the value giving the smallest SSR. It is consistent estimate of the threshold. When the lag order and delay parameter is known, the number of estimations to be made is $\omega N$ in SETAR (2) model (one threshold). $N$ is length of the sample. For three regimes SETAR (like model 1) there are two thresholds to be determined $\left(\lambda_{1}, \lambda_{2}\right)$ and the number of estimations increases quadratically. The computation rises more when the delay parameter is included in the grid search. Hansen (1999) proposed the sequential estimation approach to save computation. Indeed, it is originally proposed by Bai (1997) and Bai and Perron (1998) to the change points. The proposition based on similarities between the threshold and the change points models. The sequential approach suggests step wise search instead of jointly search. In first step the grid search is executed for SETAR (2) model and obtain the threshold $\lambda_{1}$. In second step by fixing $\lambda_{1}$ the search is executed only for $\lambda_{2}$.

Although the grid search is a useful method for determining threshold values, it does not say anything about which SETAR model should be chosen or whether the nonlinear model is superior to the linear model. To test the nonlinear structure, Keenan (1985), Tsay (1986), Chan and Tong (1990), Hansen (1996, 1997 and 1999) developed various tests with the similar structure. Since the test developed by B. Hansen can statistically determine which SETAR model is more suitable for up to three regimes, it is preferred more frequently in the empirical literature.

The test statistic of the hypothesis of SETAR (i) against SETAR ( $\mathrm{j}$ ) is following:

$$
\begin{aligned}
& F_{i j}^{H} \\
& =n\left[\frac{S S R_{i}-S S R_{j}}{S S R_{j}}\right]
\end{aligned}
$$

where $(i<j)$ and $\mathrm{H}$ is used to denote Hansen. When $i=1$, the null hypothesis is linear model. Hansen (1997, $\mathrm{s}: 4)$ stated that since $\lambda$ is not identified, the asymptotic distribution of $F_{i j}^{H}$ is not $X^{2}$. To generate the critical values, Hansen (1999) offered a bootstrap-based approach. In this procedure, firstly SETAR (i) is estimated and the parameters and the residuals are obtained. Using them a $y^{*}$ series is simulated and $F_{i j}^{H}$ statistic is calculated. The bootstrap distribution is generated repeating this a large number of times. We use Hansen Test for this test procedure.

Whenever nonlinear structure is investigated for a real exchange rate, it is a natural question whether this process is stationary or not. Numerous tests have been developed that test the presence of unit root in nonlinear processes. However, most of these are useable for specific type models. The test which is developed by Bec et al. (2004) suitable for our model, because the data generating process is SETAR (3) and the corridor regime is defined quite general form.

Bec et al. (2004) defined the stationarity as a globally which is popularized by Balke and Fomby (1997). A globally stationary process is defined such that corridor regime might a random walk process but outer regimes is mean reverting. They proposed the supremum tests (supLR, supWald and supLM) for testing unit root. These tests were offered by Davies (1987) to testing a structural change when nuisance parameter is present only under the alternative. Bec et al. (2004) showed that asymptotic distributions of the sup tests are pivotal if an interval $\lambda \in\left[\bar{\lambda}_{T}, \underline{\lambda}_{T}\right]$ is chosen in an appropriate manner. Because of this property critical values can be computed empirical.

In the test procedure, under null hypothesis a series is simulated as follows;

$$
\begin{gathered}
\Delta y_{t}=\mu+\alpha_{1} \Delta y_{t-1}+\ldots+\alpha_{p-1} \Delta y_{t-p+1} \\
+\sigma \varepsilon_{t}
\end{gathered}
$$

where $\varepsilon_{t}$ drawn from iid $\mathbb{N}(0,1), p$ is determined by any information criteria and the parameters are assigned by estimating model 3 with real data. To compute critical value under alternative hypothesis, a model of SETAR(m) is required. For $m=3$ (model 1), it is as follows; 
$\Delta \mathrm{y}_{t}$

$=\left\{\begin{array}{l}\mu_{1}+\alpha_{11} \Delta y_{t-1}+\ldots+\alpha_{1 p-1} \Delta y_{t-p+1}+\rho_{1} y_{t-1}+\sigma \varepsilon_{t} y_{t-1} \leq-\lambda . \\ \mu_{2}+\alpha_{21} \Delta y_{t-1}+\ldots+\alpha_{2 p-1} \Delta y_{t-p+1}+\rho_{2} y_{t-1}+\sigma \varepsilon_{t} \lambda>y_{t-1}>-\lambda(4) \\ \mu_{3}+\alpha_{31} \Delta y_{t-1}+\ldots+\alpha_{3 p-1} \Delta y_{t-p+1}+\rho_{3} y_{t-1}+\sigma \varepsilon_{t} y_{t-1} \geq \lambda .\end{array}\right.$

By estimating both restricted $\left(\rho_{1}=\rho_{2}=\rho_{3}=0\right)$ and unrestricted models, the residuals are obtained and the following $L R$ statistics are calculated.

$$
\begin{aligned}
& \operatorname{LR}(\lambda) \\
& =N \ln \left(\frac{\tilde{\sigma}^{2}}{\hat{\sigma}^{2}}\right)
\end{aligned}
$$

$N$ is size of sample. $\tilde{\sigma}^{2}=\sum_{1}^{T} \varepsilon_{t}^{2} / N$ is calculated from restricted model. $\hat{\sigma}^{2}$ calculated by same way from unrestricted one. This process is repeated several thousand times to obtain critical values. Bec at al. (2004) showed that sup LR test outperform the ADF test. However, power of sup LR test (and also ADF) fall dramatically as $\rho_{1}$ approaches 0 . We use BBC Test for this unit root test procedure.

\section{DATA AND ESTIMATION}

In this study, we use the real effective exchange rate indexes published by the Central Bank of the Republic of Turkey. They are calculated based on CPI and PPI by the trade weighted average. The analysis covers the period 1994M01-2020M08 and the data is monthly frequency. The data are used in logarithmic form. From these data we generate de-meaned and de-trended ones for each (CPI and PPI based). We use cubic approach to decompose the real exchange rates into a trend $\left\{\tau_{t}\right\}$ and a stationary component $\left\{q_{t}-\tau_{t}\right\}$. In this approach, it is assumed that $x_{t}=m_{t}+w_{t}$ and $m_{t}=\beta_{0}+\beta_{1} t+\beta_{2} t^{2}+\beta_{3} t^{3}$. The stationary series $w_{t}$ is obtained smoothing splines methodology (see Shumway and Stoffer, 2016:68). We denote a series as ${ }_{j}^{i} q_{t}$. CPI and PPI are demonstrated $c$ and $p$ respectively; $j=c, p$. De-meaned and de-trended are demonstrated $d m$ and $d t$ respectively $i=d m, d t$.

$\mathrm{R}$ programming is used for calculations, estimations and graphics.

We first test unit root for the raw data by conventional ADF test which ignore nonlinearity and structural break. The results of the test are presented in Table 1. The results suggest that both series is not stationary in linear nature.

We use sequential approach to the estimation of nonlinearities. At first, some preliminary investigation needs to be done. They are the determining of lag order $p$ and the interval $\left[\bar{\lambda}_{T}, \underline{\lambda}_{T}\right]$ over which execute to the grid search. Granger and Teräsvirta (1993) propose to use the partial autocorrelation function (PACF) to determine the number of lags. We will take this selection criteria as only the starting point. If the residuals have autocorrelation, we will augment the lag. The PACF for the raw data is shown in Table 2.

\begin{tabular}{ccccccc}
\multicolumn{7}{c}{ Table 2: PACF functions } \\
\hline lag & 1 & 2 & 3 & 4 & 5 & 6 \\
\hline$q_{t}^{C P I}$ & $0,97^{* *}$ & $-0,24^{* *}$ & 0,09 & 0,02 & 0,04 & 0,10 \\
$q_{t}^{P P I}$ & $0,97^{* *}$ & $-0,26^{* *}$ & 0,04 & 0,06 & 0,02 & 0,09 \\
\hline
\end{tabular}

***,**,* indicate significance at $10 \%, 5 \%$ and $1 \%$ levels.

The first and second partial autocorrelation coefficients are statistically different from zero at the $5 \%$ significance level. For $p=2$, ADF type version of model 1 becomes,

$$
\begin{aligned}
& \Delta q_{t} \\
& = \begin{cases}\mu_{1}+\alpha_{11} \Delta q_{t-1}+\rho_{1} q_{t-1}+\varepsilon_{t} & \text { if } y_{t-1} \leq-\lambda \\
\mu_{2}+\alpha_{21} \Delta q_{t-1}+\rho_{2} q_{t-1}+\varepsilon_{t} & \text { if } \lambda>y_{t-1}>-\lambda \\
\mu_{3}+\alpha_{31} \Delta q_{t-1}+\rho_{3} q_{t-1}+\varepsilon_{t} & \text { if } y_{t-1} \geq \lambda\end{cases}
\end{aligned}
$$

This model was used many times in the empirical works of SETAR (3) model for PPP. In traditional wisdom the process is stationary if $\rho<0$. Also, the half-life a shock is $\ln (2) / \ln \rho$. It is measure that how long time it takes for half of a shock to PPP to be extinguished.

Each series has 320 observations. The trim ratio is determined as $10 \%$. It is guaranteed that the length of each of outer regimes is minimum 32 and also that the

\begin{tabular}{|c|c|c|c|c|c|c|}
\hline & Linear & \multicolumn{2}{|c|}{ SETAR (2) } & \multicolumn{3}{|c|}{ SETAR (3) } \\
\hline & SSR & $\lambda_{1}$ & SSR & $\lambda_{1}$ & $\lambda_{2}$ & SSR \\
\hline \multicolumn{7}{|c|}{ De-meaned } \\
\hline${ }_{c}^{d m} q_{t}$ & 0,366 & $-0,177$ & 0,325 & $-0,177$ & 0,155 & 0,318 \\
\hline${ }_{p}^{d m} q_{t}$ & 0,360 & $-0,139$ & 0,316 & $-0,139$ & 0,086 & 0,310 \\
\hline \multicolumn{7}{|c|}{ De-trended } \\
\hline${ }_{c}^{d t} q_{t}$ & 0,328 & 0,048 & 0,268 & $-0,054$ & 0,048 & 0,261 \\
\hline${ }_{p}^{d t} q_{t}$ & 0,320 & 0,042 & 0,254 & $-0,041$ & 0,042 & 0,253 \\
\hline
\end{tabular}
estimated SETAR model is not driven by some outlier.

The results of the grid search with the sequential approach

\begin{tabular}{|c|c|c|c|c|c|c|c|c|c|c|c|c|}
\hline \multirow{2}{*}{ Model } & \multirow{2}{*}{$q_{t}^{C P I}$} & \multirow{2}{*}{$q_{t}^{P P I}$} & \multicolumn{3}{|c|}{ Critical Value } & \multirow{2}{*}{${ }^{d t} q_{t}$} & \multirow{2}{*}{$\begin{array}{l}0,328 \\
0,320\end{array}$} & \multirow{2}{*}{$\begin{array}{l}0,048 \\
0,042\end{array}$} & \multirow{2}{*}{$\begin{array}{l}0,268 \\
0,254\end{array}$} & \multirow{2}{*}{$\begin{array}{l}-0,054 \\
-0,041\end{array}$} & \multirow{2}{*}{$\begin{array}{l}0,048 \\
0,042\end{array}$} & \multirow{2}{*}{$\begin{array}{l}0,261 \\
0,253\end{array}$} \\
\hline & & & $\% 10$ & $\% 5$ & $\% 1$ & & & & & & & \\
\hline Intercept & $-1,70$ & $-2,54$ & $-2,57$ & $-2,87$ & $-3,45$ & \multirow{2}{*}{\multicolumn{7}{|c|}{$\begin{array}{l}\text { Notes: Following existing studies, delay parameter is set unity. In second } \\
\text { stage of the sequential estimation, } \% 10 \text { neighbor of } \lambda_{1} \text { is excluded from grid } \\
\text { search such that the corridor regime has enough observations. }\end{array}$}} \\
\hline Intercept and Trend & $-1,50$ & $-2,31$ & $-3,14$ & 3,42 & 3,99 & & & & & & & \\
\hline
\end{tabular}
over ${ }_{c}^{d m_{c}} q_{t},{ }_{c}^{d t} q_{t},{ }_{p} q_{t}$ and ${ }_{p}^{d t} q_{t}$ are reported in Table 3 .

Table 3: The grid search results 
Compared to the linear models, the nonlinear model estimates reduced SSRs by $\% 10-20$. Except ${ }_{p} q_{t}$, the threshold values are approximately symmetrical. The symmetry is an essential property in Band-TAR models. It is expected to be for exchange rates among developed country currencies. Since Turkey is a developing country and the speculative expectations may differ between outer regimes (high and low regimes), the symmetry may not occur. Although the pre-estimation results are promising, we will not test the validity of this property.

There are two hypotheses that need to be tested. These are linearity and stationarity. For model 6, the null hypothesis of these tests is as follows, respectively.

$H_{0}: \quad \rho_{1}=\rho_{2}=\rho_{3}$ and $\mu_{1}=\mu_{2}=\mu_{3}$

$H_{0}: \quad \rho_{1}=\rho_{2}=\rho_{3}=0$

For the null hypothesis of linearity, Hansen Test critical values are produced by bootstrap method from 2000 replications for each series. For null hypothesis of globally stationarity, BBC Test critical values are produced from 5000 replications with the average parameters values that is dictated by the de-meaned data. The critical values and test statistics are reported in Table 4.

Table 4: Stationarity and linearity test result

\begin{tabular}{|c|c|c|c|c|c|c|}
\hline \multicolumn{4}{|l|}{ Series } & \multicolumn{3}{|c|}{ Critical Values } \\
\hline${ }^{d m}{ }_{c} q_{t}$ & ${ }^{d m}{ }_{p} q_{t}$ & ${ }^{d t} q_{t}$ & ${ }_{p}^{d t} q_{t}$ & $90 \%$ & $95 \%$ & $99 \%$ \\
\hline \multicolumn{7}{|c|}{ Stationarity test } \\
\hline 12,83 & 18,94 & - & - & 15,59 & 18,91 & 24,7 \\
\hline \multicolumn{7}{|c|}{ Linearity test } \\
\hline 48.30 & - & - & - & 24,96 & 27,22 & 33,08 \\
\hline- & 51,34 & - & - & 25,67 & 28,66 & 36,19 \\
\hline - & - & 82,15 & - & 24,21 & 27,49 & 33,06 \\
\hline- & - & - & 84,74 & 24,80 & 28,50 & 35,57 \\
\hline
\end{tabular}

The tests are revealed that the null of linearity against SETAR (3) is rejected for all of the series at level of $\% 1$ and that unit root is rejected for ${ }_{p}^{d m} q_{t}$ at level of $\% 5$ but not rejected for ${ }^{d m}{ }_{c} q_{t}$ at conventional levels (10\% or better).

The results obtained from the estimation of model 6 is presented in Table 5. Since ${ }_{c}^{d m_{c}} q_{t}$ is non stationary, it is not estimated. In addition, we impose the restriction of $\mu_{i}=0$ as in Kapetanios and Shin (2002).

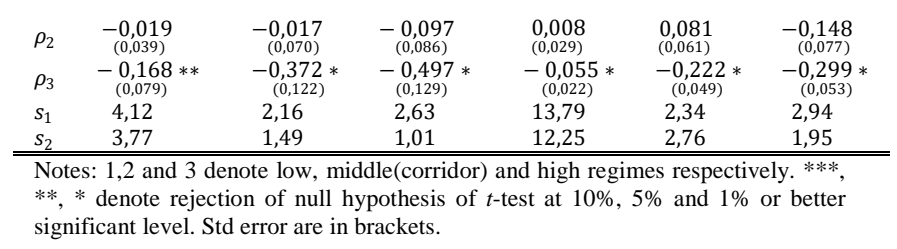

According to t-test, in each model $\rho_{1}$ and $\rho_{3}$ are statistically different from zero at level $5 \%$ or better, but null of zero hypothesis is not rejected for the corridor regimes. Since the outer regimes are stationary and the corridor regime is non stationary, the process of SETAR (3) is globally stationary. t-test confirm the BBC test. The estimated parameters of de-trended series indicate that the corridor regimes have unit root and the outer regimes have tendency property. This confirms the existence of the inactivity band caused by transaction costs and other factors even in the presence of the trend component.

In the last two columns, the half-life duration is calculated for $\rho_{1}$ and $\rho_{3}$ respectively. It is measure that how long time it takes for half of a shock to PPP to be extinguished. In de-trended series, the durations are close in the restricted and unrestricted estimation of same series. But in the de-meaned series, it is more than 3 times larger in the restricted model than the unrestricted one. In all models except one, the duration is longer in lower regime than in upper regime. This is probably due to speculative expectations formed by historical experiences. According to the estimation results, convergence exists only in outer regimes and it is fast. In other words, after a real exchange rate shock happens it quickly turns to the corridor regime. The corridor regime is already a random walk process.

\section{CONCLUSION}

The empirical analysis executed in this study provides strong evidence the nonlinearity with three regimes for real effective exchange rates based on CPI and PPI in the period of 1994M01-2020M08. According to the nonlinear stationary test for de-meaned data, the CPI based real effective exchange rate is non stationary and also there is weak statistical evidence stationarity of PPI based one. However, take into account possibility of the existence of trend component, Turkish real effective exchange rates are well characterized by nonlinear process with inactivity band and tendency properties. While these findings support the transaction costs hypothesis, they do not strongly support the validity of the PPP hypothesis
Table 5: SETAR estimates

\begin{tabular}{|c|c|c|c|c|c|c|}
\hline & $\Delta_{p}^{d m} q_{t}$ & $\Delta^{d t}{ }_{c} q_{t}$ & $\Delta_{p}^{d t} q_{t}$ & $\Delta_{p}^{d m} q_{t}$ & $\Delta^{d t} q_{t}$ & $\Delta_{p}^{d t} q_{t}$ \\
\hline & \multicolumn{3}{|c|}{ Non restricted models } & \multicolumn{3}{|c|}{ Restricted models } \\
\hline$\mu_{1}$ & $\begin{array}{c}-0,030 * * \\
(0,010)\end{array}$ & $\begin{array}{c}-0,002 \\
(0,009)\end{array}$ & $\begin{array}{c}-0,002 \\
(0,007)\end{array}$ & - & - & - \\
\hline$\mu_{2}$ & $\begin{array}{l}0,001 \\
(0,003)\end{array}$ & $\begin{array}{l}0,002 \\
(0,002)\end{array}$ & $\begin{array}{c}0,001 \\
(0,002)\end{array}$ & - & - & - \\
\hline$\mu_{3}$ & $\begin{array}{l}0,019) * * * \\
(0,012)\end{array}$ & $\begin{array}{l}0,014 \\
(0,010)\end{array}$ & $\underset{(0,009)}{0,021} * *$ & - & - & - \\
\hline$\rho_{1}$ & $\begin{array}{c}-0,155 \\
(0,060)\end{array}$ & $\begin{array}{c}-0,275 * \\
(0,082)\end{array}$ & $-\underset{(0,222)}{0,232} *$ & $\underset{(0,018)}{-0,049}$ * & $\underset{(0,039)}{-0,256} *$ & $-\underset{(0,038)}{0,210}$ * \\
\hline
\end{tabular}




\section{REFERENCES}

Alba, J. D.; Park, D. (2005), "An empirical investigation of purchasing power parity (PPP) for Turkey", Journal of Policy Modeling, 27:8, 989-1000.

Arghyrou, M. G., Boinet, V. and Martin, C. (2006), "Non-linear and non-symmetric exchange-rate adjustment: Evidence from medium- and high-inflation countries", Journal of Economics and Finance, 30:1, 38-56.

Bai, J. (1997), "Estimating Multiple Breaks One at a Time. Econometric Theory", 13:3, 315-352.

Bai, J.; Perron, P. (1998), "Estimating and Testing Linear Models with Multiple Structural Changes", Econometrica, 66:1, 47-78.

Balke, N. S.; Fomby, T. B. (1997), "Threshold Cointegration. International Economic Review", 38:3, 627-645.

Bec, F.; Ben Salem, M. and Carrasco, M. (2004), "Tests for Unit-Root versus Threshold Specification with an Application to the Purchasing Power Parity Relationship" Journal of Business \& Economic Statistics, 22:4, 382-395.

Beninga, S.; Protopapadakis, A. A. (1988), "The equilibrium pricing of exchange rates and assets when trade takes time", Journal of International Economics, 7, 129-149.

Blassa, B. (1964), "The Purchasing Power Parity Doctrine: A Reapraisal", Journal of Political Economy, 72, $584-596$.

Canzoneri, M. B.; Cumby, R. E. and Diba, B. (1996), "Relative Labor Productivity and the Real Exchange Rate in the Long Run: Evidence for a Panel of OECD Countries", NBER, Working Paper no: 5676.

Chan, K. S. (1993), "Consistency and Limiting Distribution of the Least Squares Estimator of a Threshold Autoregressive Model", The Annals of Statistics, 21:1, 520-533.

Chan, K. S.; Tong, H. (1990), "On Likelihood Ratio Tests for Threshold Autoregression", Journal of the Royal Statistical Society, Series B, $52: 3,469-476$

Chinn, M.; Johnston, L. (1996), "Real Exchange Rate Levels, Productivity and Demand Shocks: Evidence From a Panel of 14 Countries", NBER, WP:5709.

Davies, R. B. (1987), "Hypothesis Testing when a Nuisance Parameter is Present Only Under the Alternatives", Biometrika, 74:1, 33-43.

Dumas, B. (1992), "Dynamic Equilibrium and the Real Exchange Rate in a Spatially Separated World", The Review of Financial Studies, $5: 2,153-180$.

Granger, C. W.; Teräsvirta, T. (1993), Modelling nonlinear economic relationships, Oxford University Press.

Hansen, B. E. (1996), "Inference when a nuisance parameter is not identified under the null hypothesis", Econometrica, 64:2, 413-430.

Hansen, B. E. (1997), "Inference in TAR models", Studies in Nonlinear Dynamics and Econometrics, 1:2, 1-14.

Hansen, B. E. (1999), "Testing for Linearity", Journal of Economic Surveys, 13:5, 551-576.

Heckscher, E. F. (1916), "Vaxelkursens Grundval vid Pappersmyntfot", Ekonomisk Tidskrift, 18, 309-312.

Hooper, P.; Morton, J. (1982), "Fluctuations in the dollar: A model of nominal and real exchange rate determination", Journal of International Money and Finance, 1, 39-56.

Kalyoncu, H., Kula, F. and Aslan, A. (2010), "The validity of purchasing power parity hypothesis in middle east and northern africa countries", Romanian Journal of Economic Forecasting, 4, 125-131.

Kapetanios, G.; Shin, Y. (2006), "Unit root tests in three-regime SETAR models", The Econometrics Journal, 9:2, 252-278.

Keenan, D. M. (1985), "A Tukey Nonadditivity-Type Test for Time Series Nonlinearity", Biometrika, 72:1, 39-44.

Kilian, L.; Taylor, M. P. (2003), "Why is it so difficult to beat the random walk forecast of exchange rates?", Journal of International Economics, 60:1, 85-107.

Krugman, P. R. (1991), "Target Zones and Exchange Rate Dynamics", The Quarterly Journal of Economics, 106:3, 669-682.

Kruse, R. (2011), "A new unit root test against ESTAR based on a class of modified statistics", Statistical Papers, 52, 71-85.

Kula, F., Aslan, A. and Feridun, M. (2011), "Purchasing Power Parity In Mena Revisited: Empirical Evidence in the Presence of Endogenously Determined Break Points", Economic Research-Ekonomska Istraživanja, 24:1, 1-12.

Kum, H. (2012), "The Impact of Structural Break(s) on the Validity of Purchasing Power Parity in Turkey: Evidence from Zivot-Andrews and Lagrange Multiplier Unit Root Tests", International Journal of Economics and Financial Issues, 2:3, 241-245.

Morton, J.; Hooper, P. (1982), "Fluctuations in the dollar: A model of nominal and real exchange rate determination", Journal of International Money and Finance, 1, 39-56.

Obstfeld, M. (1993), "Model Trending Real Exchange Rates", Center for International and Development Economics Research, Working Paper No:C93-011.

Obstfeld, M.; Rogoff, K. (1994), "The Intertemporal Approach to the Current Account", NBER, Working Paper no: 4893.

Obstfeld, M.; Taylor, A. M. (1997), "Nonlinear Aspects of Goods-Market Arbitrage and Adjustment: Heckscher's Commodity Points Revisited", Journal of the Japanese and International Economies, 11:4, 441-479.

Sarno, L. (2000), "Real exchange rate behaviour in high inflation countries: empirical evidence from Turkey, 1980-1997", Applied Economics Letters, 7:5, 285-291.

Shumway, R. H.; Stoffer, D. S. (2016), Time Series Analysis and Its Applications (Fourth Edition b.). Pittsburgh: Springer.

Şener, S., Yılancı, V. and Canpolat, E. (2015), "Satın alma gücü paritesi ve varyasyonlarının Türkiye için sınanması", Uluslararası Yönetim İktisat ve İşletme Dergisi, 11:25, 53-63.

Taylor, M. P. (2004), "Is Official Exchange Rate Intervention Effective?", Economica, 71:281, 1-11.

Taylor, M. P., Peel, D. A. ve Sarno, L. (2001), "Nonlinear Mean-Reversion in Real Exchange Rates: Toward a Solution To the Purchasing Power Parity Puzzles", International Economic Review, 11, 1015-1042.

Tsay, R. S. (1986), "Nonlinearity tests for time series", Biometrika, 73:2, 461-466.

Williams, J. C.; Wright, B. D. (1991), Storage and commodity markets, UK: Cambridge University Press.

Y1ldırım, D. (2017), "Empirical investigation of purchasing power parity for Turkey:Evidence from recent nonlinear unit root tests", Central Bank Review, 17, 39-45.

Yıldırım, S.; Yıldırım, Z. (2012), "Reel efektif döviz kuru üzerinde kırılmalı birim kök testleri ile Türkiye için satın alma gücü paritesi hipotezinin geçerliliğinin sınanması", Marmara Üniversitesi İ.B.B Dergisi, 33:2, 221-238. 